\title{
Seedling Growth of Three Big Sagebrush Subspecies under
}

\section{Controlled Temperature Regimens}

\author{
R. O. HARNISS AND W. T. McDONOUGH
}

Highlight: Seedlings of three subspecies of big sagebrush, Artemisia tridentata, (tridentata, vaseyana, and wyomingensis) were grown for 10 weeks under temperature regimens programed to simulate below-average, average, and above-average conditions during late spring to early summer in the native habitat. Growth of seedlings of all subspecies was reduced under the below-average temperature regimen; but no difference in growth occurred between subspecies under any one regimen.

Investigators of brush control and revegetation on sagebrush-grass range have observed that there are good years for big sagebrush (Artemisia tridentata) invasion and reestablishment in treated areas (Pechanec, 1945; Mueggler, 1956; Johnson, 1958; Daubenmire, 1970). Possible reasons for these good years include the occurrence of favorable temperatures for seed germination or seedling growth during some critical period, such as late spring when soil water in the superficial layers is adequate for these processes. In a study of germination of three subspecies of big sagebrush (tridentata, vaseyana, and wyomingensis) at temperatures in the $30^{\circ} \mathrm{C}$ to $2^{\circ} \mathrm{C}$ range (McDonough and Harniss, 1974a, b), no differences were found within subspecies. Also, differences between subspecies were small, except that vaseyana seed required a stratification treatment to attain germination comparable to the others. These results indicated that temperature-sensitive germination is not a critical factor involved in successful reestablishment. The study reported here was undertaken to determine temperature sensitivity of seedling growth of the same subspecies under controlled temperature conditions.

\section{Procedures}

Separate collections of seeds were made from three individual plants of each subspecies on or near the Sheep Experimental Range, Dubois, Idaho, in the fall of 1971. Seeds were allowed to imbibe in petri dishes on filter paper saturated with distilled water for 50 days at $2^{\circ} \mathrm{C}$ before being transferred to temperature alternations of $20^{\circ} \mathrm{C} / 10^{\circ} \mathrm{C}$ for germination. This stratification treatment and temperature alternation gave rapid and high germination in a previous study (McDonough and Harniss, 1974a, b). When the cotyledons were fully expanded, seedlings were planted in native topsoil in 3-liter containers, three containers for each individual collection and temperature regimen. After a week's growth under controlled conditions, seedlings were thinned ( 2 to 4 uniform seedlings per container).

Temperature alternations in three growth chambers were started at $14^{\circ} \mathrm{C} / 1^{\circ} \mathrm{C}$ ( 12 hour $/ 12$ hour) and increased weekly by increments of $0.56^{\circ} \mathrm{C}, 1.11^{\circ} \mathrm{C}$, or $1.67^{\circ} \mathrm{C}\left(1^{\circ} \mathrm{F}, 2^{\circ} \mathrm{F}\right.$, or $3^{\circ} \mathrm{F}$ ) for 10 weeks. These weekly temperature increments simulated below-average, average, and above-average temperature regimens in late spring and early summer as determined by 45 years of weather data from near the collection sites. The photoperiod was increased at a rate of 15 minutes per week to a 14-hour maximum, corresponding to

The authors are, respectively, range scientist and plant physiologist, U. S. Department of Agriculture, Forest Service, Intermountain Forest and Range Experiment Station, Ogden, Utah, stationed in Logan, Utah at the Forestry Sciences Laboratory, maintained in cooperation with Utah State University.

Manuscript received October 7, 1974.

increases in the duration of sunlight during late spring and early summer. The irradiance level during the photoperiod in the three chambers was $76 \times 10^{4} \mathrm{ergs}^{-2} \mathrm{sec}^{-1}$.

Measurements of shoot height were taken weekly. The experiment was terminated at the tenth week, when shoot growth had nearly ceased. Plants were harvested and individual ovendry weights of shoots and roots were determined. Results were evaluated by variance analyses and multiple range tests at the $5 \%$ level of significance.

\section{Results and Discussion}

There were significant differences in growth among individuals within subspecies under all temperature regimens. Such differences may have resulted from normal cross-pollination in these subspecies and consequent differences in genetic composition of individual seedlings that affect growth.

Significant differences were found in growth of shoots and roots in relation to temperature (Table 1). Shoot height and weight and root weight were reduced under below-average conditions. No differences in growth were observed between subspecies under the temperature regimens. Thus, there is no physiological differentiation of the subspecies with reference to the extent of seedling growth as influenced by the temperatures tested. Compared to the other subspecies, vaseyana occurs at higher elevations and its seeds require a stratification treatment for high and rapid germination (McDonough and Harniss, 1974b); however, there is no evidence here of an adaptation of seedling growth to lower temperatures.

In all subspecies, although growth is better at average and above-average temperatures, the below-average conditions are still well within the range of tolerance for this sensitive stage

Table 1. Root weight, shoot weight, and shoot height of three subspecies of big sagebrush (Artemisia tridentata) at three advancing temperature regimens. ${ }^{1}$

\begin{tabular}{|c|c|c|c|c|}
\hline \multirow{2}{*}{$\begin{array}{l}\text { Measurement and } \\
\text { weekly temperature } \\
\text { increments }\left({ }^{\circ} \mathrm{C}\right)\end{array}$} & \multicolumn{3}{|c|}{ Subspecies } & \multirow[b]{2}{*}{ Average } \\
\hline & tridentata & wyomingensis & vaseyana & \\
\hline \multicolumn{5}{|c|}{ Root weight $(\mathrm{g})$} \\
\hline 1.7 & 0.10 & 0.14 & 0.16 & $0.14^{\mathrm{a}}$ \\
\hline 1.1 & .16 & .16 & .15 & $16^{\mathrm{a}}$ \\
\hline 0.6 & .06 & .11 & .07 & $.08^{\mathrm{b}}$ \\
\hline Average & $0.10^{\mathrm{a}}$ & $0.14^{\mathrm{a}}$ & $0.12^{\mathrm{a}}$ & \\
\hline \multicolumn{5}{|l|}{ Shoot weight (g) } \\
\hline 1.7 & 0.34 & 0.38 & 0.42 & $0.38^{\mathrm{a}}$ \\
\hline 1.1 & .39 & .31 & .29 & $.33^{\mathrm{a}}$ \\
\hline 0.6 & .23 & .27 & .18 & $.22^{\mathrm{b}}$ \\
\hline Average & $0.31^{\mathrm{a}}$ & $0.32^{\mathrm{a}}$ & $0.30^{\mathrm{a}}$ & \\
\hline \multicolumn{5}{|l|}{ Shoot height (mm) } \\
\hline 1.7 & 78 & 82 & 87 & $82^{a}$ \\
\hline 1.1 & 79 & 84 & 75 & $79^{a}$ \\
\hline 0.6 & 67 & 77 & 56 & $66^{b}$ \\
\hline Average & $74^{\mathrm{a}}$ & $81^{a}$ & $73^{\mathrm{a}}$ & \\
\hline
\end{tabular}

${ }^{1}$ Average growth values among temperature regimens and subspecies with the same letter in superscript do not differ significantly. 
of development. These results suggest that year-to-year temperature variations are not critical in the determination of successful reestablishment in these subspecies.

\section{Literature Cited}

Daubenmire, R. F. 1970. Steppe vegetation of Washington. Wash. Agr. Exp. Sta. Tech. Bull. $62.132 \mathrm{p}$.

Johnson, W. M. 1958. Reinvasion of big sagebrush following chemical control. J. Range Manage. 11:169-172.

McDonough, W. T., and R. O. Harniss. 1974a. Effects of temperature germination in three subspecies of big sagebrush. J. Range Manage. 27:204-205.

McDonough, W. T., and R. O. Harniss. 1974b. Seed dormancy in Artemisia tridentata Nutt. subspecies vaseyana Rydb. Northwest Sci. 48(1): 17-20.

Mueggler, W. F. 1956. Is sagebrush seed residual in soil or is it wind-borne: U.S. Dep. Agr., Forest Serv., Intermountain Forest and Range Exp. Sta. Res. Note 35.10 p.

Pechanec, J. F. 1945. Indicators of downward trend in sagebrush-perennial grass ranges grazed by sheep in spring and fall. U. S. Dep. Agr., Forest Serv., Intermountain Forest and Range Exp. Sta. Res. Pap. 12. 2 p. 